\title{
HUBUNGAN KEMAMPUAN WAKTU REAKSI DAN FLEKSIBILITAS ATLET UKM TAEKWONDO UPI DENGAN HASIL TENDANGAN DOLLYO-CHAGI
}

\author{
R. Muhamad Delpas Giandika, Nurlan Kusmedi, Agus Rusdiana \\ Fakultas Pendidikan Olahraga dan Kesehatan \\ Universitas Pendidikan Indonesia, Jl. Dr. Setiabudhi No. 299 Bandung \\ Em@il: giandika.delpas@ gmail.com
}

\begin{abstract}
Abstrak
Waktu reaksi dan fleksibilitas merupakan komponen-komponen kondisi fisik penting bagi atlet Taekwondo untuk memproduksi sebuah tendangan, salah satunya tendangan dollyochagi. Penelitian ini bertujuan untuk mengetahui apakah terdapat hubungan antara kemampuan waktu reaksi dan fleksibilitas atlet Taekwondo dengan hasil tendangan dollyochagi. Penelitian ini menggunakan pendekatan deskriptif dengan metode korelasi. Populasi sekaligus sampel yang diambil datanya adalah atlet UKM Taekwondo UPI dengan total 10 orang dengan menggunakan teknik purposive sampling. Instrumen yang digunakan adalah tes whole body reaction time, sit and reach, dan tes tendangan dollyo-chagi dengan menggunakan Protektor Scoring System (PSS). Hasil penelitian ini menunjukan bahwa terdapat hubungan waktu reaksi dan fleksibiltas dengan hasil tendangan dollyo-chagi. Selain itu, banyak komponen kondisi fisik yang dapat membantu atau menjadi faktor lain dalam melakukan sebuah tendangan dalam cabang olahraga taekwondo. sehingga nantinya akan sangat membatu sekali dalam pengembangan prestasi atlet nanti dan menjadi bahan pertimbangan lebih kepada para pelatih.
\end{abstract}

Kata kunci: waktu reaksi,fleksibilitas, taekwondo, tendangan dollyo-chagi

\section{PENDAHULUAN}

Kemampuan hewan untuk mengatasi perubahan lingkungan untuk pemeliharaan homeostasis tergantung pada integritas komunikasi sel dan respon yang diberikan oleh berbagai sistem dalam hal persepsi sensorik dan respon motorik. Gerakan motorik atau adalah suatu istilah yang digunakan untuk menggambarkan perilku gerakan yang dilakukan oleh tubuh manusia. Pegendalian motorik mempelajari postur dan gerak serta mekanisme yang menyebabkanya. Terdapat berbagai jenis gerakan motorik, salah satunya adalah gerakan reflek.
Gerak reflex adalah gerakan yang dilakukan tanpa sadar dan merupakan respon seger setelah adanya rangsangan. Pada manusia gerak reflex terjadi melalui (reflex arc), namun reflex-reflex ini sangat penting artinya didalam mendiagnosis dan melokalisasi lesi neurologi. Gerak reflex dapat dilatih misalnya pengulanga dari gerakan motorik pada latihan olah raga atau pengaitan dari rangsang oleh reaksi otomatis selama pengkondisian klasikal.

Didalam suatu pergerakan pasti dibutuhkan waktu yang relative cukup untuk melakukan suatu perpindahan gerak, maka dibutuhkanlah waktu reaksi dalam akan hal ini. Waktu respon seharusnya menjadi faktor terbaik untuk 
pengelolaan homeostasis yang kita sebut sebagai waktu reaksi. Waktu reaksi adalah umlah waktu yang dibutuhkan oleh organisme untuk bereaksi sejak rangsang muncul.

Dalam pelaksanaan aksi-aksi motorik atau gerakan-gerakan olahraga ada 5 indra penerima informasi yaitu : visual (penglihatan), akustik (penalaran), taktil (kulit), kinestik (otot), dan vertibular (alat kesimbangan). Kelima indra itu tidak hanya berperan dalam menerima informasi tetapi juga berperan dalam penerimaan feedback, yaitu tentang gerak yang sedang berlangsung. Berdasarkan feedback ini dapat dilakukan pengendalian dan pengaturanpengaturan gerakan-gerakan yang dilakukan misalnya : pengaturan impuls-impuls kekuatan, pengatura dan pengendalian arah gerak.

Sangat di butuhkan pergerakan yang baik apa lagi ketika dalam suatu pertandingan, pertandingan baik itu taekwondo maupun karate merupakan pertarungan dengan resiko full body contact. Dimana ada kalanya terjadi benturan ataupun terkena serangan lawan, tapi hal itu tak akanlah terjadi ketika seorang atlet memiliki keterampilan antisipasi yang baik.

Waktu reaksi memang sangat dibutuhkan seorang atlet khususnya pada saat pertandingan, memperkirakan kapan waktu menyerang dan kapan waktu bertahan. Mendapatkan serangan dari lawanpun itu menjadi suatu stimulus, apa yang akan dilakukan bila ketika lawan menyerang. Keterampilan ini juga harus di dukung oleh faktor keterampilan lain seperti kelentukan/fleksibilitas yang baik sehingga dapat membuat sebuah pergerakan sese orang pun menjadi lebih baik.

Taekwondo mulai berkembang di Indonesia pada tahun 70-an, dimulai aliran Taekwondo yang berafiliasi ke ITF (International Taekwondo Federation) yang waktu itu bermarkas besar di toronto Kanada, aliran ini dipimpin dan dipelopori oleh General Choi Hong $\mathrm{Hi}$, kemudian berkembang juga aliran Taekwondo yang berafaliasi ke WTF (The World Taekwondo Federation) yang berpusat di Kukkiwon, Seoul, Korea Selatan dengan Presiden Dr. Un Yong Kim.
Taekwondo Indonesia telah berkembang di seluruh provinsi di Indonesia dan diikuti secara aktif oleh lebih dari 200.000 anggota, angka ini belum termasuk yang tidak secara aktif berlatih. Taekwondo telah dipertandingkan sebagai cabang olahraga resmi di arena PON. Beberapa atlet yang pernah berjaya membela negara di event internasional antara lain seperti : Budi Setiawan, Rahmi Kurnia, Siauw Lung, Yefi Triaji, Lamting, Yeni Latif, Dirk Richard, dan sebagainya di masa tahun 1986-1993. Pada generasi berikutnya antara lain seperti Yuana Wangsa Putri yang mewakili Indonesia di event Olympic Games 2000 Sidney dan Ika Dian Fitria yang berhasil meraih medali emas pada Kejuaraan Dunia Yunior bulan November 2000, pada tahun 2001 - 2011 generasi berikutnya antara lain Siska Permata Sari, Merry Wandra, Fransisca Valentine, Rizal Samsir, Basuki Nugroho dan sebagainya. masih banyak lagi para atlet taekwondo yang telah bersumbangsih dalam perkembangan taekwondo di Indonesia.

Taekwondo merupakan salah satu cabang olahraga beladiri yang berkembang di Indonesia maupun di dunia pun sudah ada dan sudah dipertandingkan. Taekwondo berasal dari negara Korea Selatan, Taekwondo berasal dari tiga kata yaitu Tae berarti kaki / menghancurkan dengan teknik tendangan, Kwon artinya tangan / menghantam dan mempertahankan diri dengan teknik tangan, Do artinya seni.keunikan taekwondo.

Cabang olahraga bela diri ini sebenarnya memiliki beberapa keterampilan yang baik sehingga nantinya akan dihubungkan dengan baik itu dari segi teknik yang nantinya akan di hasilkan pada saat pertandingan. Didalam olahraga tersebut sangatlah dibutuhkan keterampilan-keterampilan gerak yang amat cukup sangat baik. Terutama ketika dalam pertandingan banyak komponen-komponen yang harusnya menjadi faktor pendukung untuk mengarah kearah prestasi.

Pada kenyataannya atau berdasarkan fakta bahwa tendangan dalam cabang olahraga taekwondo khususnya dollyo-chagi merupakan 
tendangan yang paling sering digunakan oleh para atlet taekwondoin, tetapi pada umumnya para atlet kadang tidak tahu dalam melakukannya kapan dan saat separti apa tendangan ini harusnya dilakukan. Terdapat beberapa keadaan dimana ketika atlet yang bertanding melakukan tendangan dengan kurang tepat seperti, ketika ada serangan seorang atlet tidak bisa melakukan serangan balasan, terjadinya tendangan yang berbarengan sehingga terjadi benturan yang tidak tepat atau tidak mengenai sasaran, melakukan serangan yang tidak tepat tanpa dulu melihat pergerakan lawan dapat mengakibatkan tendangan yang tidak akan menghasilkan poin. Dari beberapa kejadian maka terlihat bahwa ada kesiapan yang kurang baik itu berupa waktu, ketepatan dalam bereaksi dan kondisi fisik yang sekiranya belum siap, jadi peneliti berharap nantinya dalam penelitian ini bisa dijadikan acuan bahwa waktu reaksi dan fleksibilitas dalam pertandinagan adalah komponen yang sangatlah penting dimana nantinya atlet bisa melakukan tendangan dengan kesiapan serta waktu yang tepat.

Tujuan penelitian yang ingin dicapai penulis adalah ingin meengetahui tingkat kemampuan waktu reaksi dan fleksibilitas serta hasil tendangan dollyo chagi atlet UKM Taekwondo UPI. Selanjutnya ingin mengetahui hubungan antara tingkat kemampuan waktu reaksi atlet dengan hasil tendangan dollyo-chagi, hubungan antara tingkat kemampuan fleksibilitas atlet dengan hasil tendangan dollyo-chagi dan hubungan tingkat kemampuan waktu dengan dengan fleksibilitas atlet dengan hasil tendangan dollyo-chagi.

\section{METODE}

Metode yang di gunakan adalah menggunakan metode kuantitatif deskriptif korelasional. Sebanyak 10 Atlet UKM Taekwondo UPI dijadikan subjek penelitian. Instrumen yang digunakan adalah tes whole body reaction time untuk mengukur waktu reaksi, sit and reach untuk mengukur fleksibitas, dan tes tendangan dollyo-chagi dengan menggunakan PSS. Lokasi pengambilan data dilakukan di dua tempat, yakni di laboratorium ilmu keolahragaan FPOK UPI dan PENGPROV TI JABAR.

\section{HASIL DAN PEMBAHASAN}

Setelah memperoleh data dari penelitian yang telah dilakukan, maka langkah selanjutnya yaitu melakukan pengolahan data dengan menggunakan rumus yang sesuai dengan masalah yang diajukan sebelumnya. Proses pengolahan data ini harus dilakukan dengan sangat baik dan benar, serta penuh ketelitian karena akan menentukan kualitas dan hasil penelitian yang dilakukan.

Berdasarkan analisis terhadap data yang diperoleh melalui pendekatan statistik, maka dapat diperoleh gambaran mengenai penemuanpenemuan hubungan antara hasil waktu reaksi dan fleksibilitas dengan hasil tendangan dollyochagi atlet UKM Taekwondo UPI. Dimana terdapat hubungan yang signifikan antara kemampuan waktu reaksi dan fleksibilitas atlet UKM Taekwondo UPI dengan hasil Tendangan dollyo-chagi, bukan hanya beberapa faktor diatas yang mempengaruhi hasil tendangan dollyo chagi, tetapi faktor dan komponen lainpun sangat mendukung terhadap tendangan dollyo-chagi.

Uji normalitas bertujuan untuk mengetahui apakah data tersebut normal atau tidak, serta untuk menentukan langkah selanjutnya. Dari semua data yang masuk, baik Hasil tes Waktu Reaksi dan Fleksibilitas, semua data normal.

Pada pengujian hipotesis digunakan uji korelasi bivariate parametric. Hasil analisis dapat dilihat pada tabel 1 .

Tabel 1. Hasil Perhitungan Korelasi

\begin{tabular}{|lcl|}
\hline Variable & No & Korelasi \\
\hline $\begin{array}{l}\text { Reaksi dengan Hasil } \\
\text { Tendangan Dollyo-Chagi }\end{array}$ & 10 & -0.660 \\
\hline $\begin{array}{l}\text { Fleksibilitas dengan Hasil } \\
\text { Tendangan Dollyo-Chagi }\end{array}$ & 10 & 0.795 \\
\hline
\end{tabular}


Data dalam penelitian ini menunjukan bahwa diperoleh korelasi reaksi dengan hasil tendangan dollyo-chagi sebesar -0.660. Tanda “_“ (negatif) pada output menunjukan adanya arah hubungan yang berlawanan, dapat diartikan bahwa semakin cepat waktu reaksi maka semakin sedikit jumlah hasil tendangan dollyo-chagi; dan sebaliknya, semakin kecil waktu reaksi akan membuat jumlah hasil tendangan dollyo-chagi semakin banyak. Sedangkan korelasi fleksibilitas dengan hasil tendangan dollyo-chagi sebesar 0.795. Pada output menunjukan adanya arah hubungan, dapat diartikan bahwa semakin besar fleksibilitas maka jumlah hasil tendangan dollyo-chagi semakin banyak

\section{KESIMPULAN}

Berdasarkan uraian dari Bab 1 sampai dengan $\mathrm{Bab} 4$, dapat menyimpulkan antara lain: (1) Tingkat Kemampuan Waktu Reaksi Atlet UKM Taekwondo UPI dengan kategori sangat baik 3 orang, baik 2 orang, cukup 1 orang, rendah 3 orang dan sangat rendang 1 orang; (2) Tingkat Kemampuan Fleksibilitas Atlet UKM Taekwondo UPI dengan kategori Sedang 6 orang, baik 1 orang dan sedang 3 orang; (3) Tingkat Hasil Tendangan Dollyo-Chagi Atlet UKM Taekwondo UPI dapat dilihat di halaman 37; (4) Terdapat Hubungan Antara Waktu Reaksi Atlet UKM Taekwondo UPI dengan Hasil Tendangan Dollyo-Chagi dalam Permainan Taekwondo; (5) Terdapat Hubungan Antara Fleksibilitas Atlet UKM Taekwondo UPI dengan Hasil Tendangan Dollyo-Chagi dalam Permainan Taekwondo; (6) Terdapat Hubungan yang Signifikan Antara Kemampuan Waktu Reaksi dan Fleksibilitas Atlet UKM Taekwondo UPI dengan Hasil Tendangan Dollyo-Chagi; (7) Bahwa banyak komponen kondisi fisik yang dapat membantu atau menjadi faktor lain dalam melakukan sebuah tendangan dalam cabang olahraga taekwondo. sehingga nantinya akan sangat membatu sekali dalam pengembangan prestasi atlet nanti dan menjadi bahan pertimbangan lebih kepada para pelatih.

\section{DAFTAR PUSTAKA}

Alim, Abdul. (2012). Latihan Fleksibilitas dengan Metode PNF, 1 (1): hlm 1-9.

Andri (2010).Pengertian sit and reach.[Online]. Tersedia : http://andrie_dedi.blogspot.com/2010/05/pengukuran-kebugaran-jasmani.html. Diakses tanggal 14 Februari 2014.

Arikunto, Suharsimi. (2010). Prosedur Penelitian. Yogyakarta : Rineka Cipta.

Boas, Vilas. dkk. (2011). Kinematic Analysis Of The Supporting Leg Between Different Weight Divisions In The Roundhouse Kick Of Taekwondo, 11(2): hlm. 423-425.

Gandi, Arif. (2013). Pengaruh Latihan Menggunakan Tahanan Karet dan Alat Bantu Pemberat Kaki Terhadap Kecepatan Tendangan Dollyo-Chagi Pada Cabang Olagraga Taekwnodo. Skripsi, Fakultas Pendidikan Olahraga dan Kesehatan, Universitas Pendidikan Indonesia.

Gavkare, A. M. (2011). Study flexibility, Agility and Reaction Timein Circus Artist, 1 (2): hlm 4955 .

Giriwijoyo, S.S.Y. dan Sidik, Z.D. (2010). Ilmu faal olahraga. Edisi 8. Bandung: Universitas Pendidikan Indonesia.

Kusmaedi, Nurlan (2008). Olahrga Lansia. Bandung : Bintang WarliArtika.

Ma'mun, Amung., dan Saputra, Yudha M (2000). Perkembangan Gerak dan Belajar Gerak. Bandung : Universitas Pendidikan Indonesia.

Med, A. (2012). Effect of Age on Audio visualand Whole Body Reaction Time, 5 (1): hlm 90-94.

Nurhasan., dan Cholil-Hasanudin, D. (2007). Modul dan Tes Pengukuran Keolahragaan. Bandung: Universitas Pendidikan Indonesia. 
Saputra, Yudha M., dan Badruzaman (2009). Perkembangan Pembelajaran Motorik. Bandung : Universitas Pendidikan Indonesia.

Suherman, Ayi (2013). Tes dan Pengukuran Keolahragaan. Bandung : Universitas Pendidikan Indonesia.

Stasiw, Michael (2014).Gambar PSS (Protektor Scoring System). [Online]. Tersedia : http://www.mdsscanada.com/pss. Diakses

Sugiyono (2013). Metode Penelitian Kuantitatif, Kualitatif, dan R\&D. Bandung : ALFABETA, $\mathrm{CV}$.

Suntoda, Andi (2009), Tes, Pengukuran, dan Evaluasi Cabang Olahraga. Bandung Universitas Pendidikan Indonesia.

Suryadi, Yoyok. V (2002). Taekwondo (tae geuk poomsae). Jogja : PT. Gramedia Pustaka Utama.

Timothy A, dkk (2008) .Pengetian kemampuan .[Online]. Tersedia di: http://www.wikipedia.org/wiki/kemampuan. Diakses 26 Februari 2014

World Taekwondo Federation (2011). World Taekwondo Federation competition rule \& interpretation. Korea Selatan. 